\title{
TANAGRA BRASILIA.
}

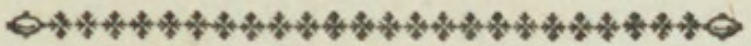

\section{CHARACTER GENERICUS.}

Rof trum conicum, acuminatum, emarginatum, bafi fubtrigonum, apice declive.

$$
\text { Lin. Syft. Nat. p. } 314 \text {. }
$$

CHARACTER SPECIFICUS, छc.

TANAGRA COCCINEA, alis caudaque nigris.

$$
\text { Lin. Syft. Nat. p. } 314 .
$$

\section{MERULA BRASILICA.}

$$
\text { Bell. av. } 319 \text {. }
$$

\section{TIJEPIRANGA.}

$$
\begin{aligned}
& \text { Raj. Syn. p. } 87 \cdot 13 \cdot \\
& \text { Will. orn. p. } 184 \cdot 18_{5} \text {. }
\end{aligned}
$$

\section{CARDINALIS.}

$$
\text { Brifl. av. 3. p. } 42 \text {. n. } 24 \cdot \text { t. } 3 \cdot \text { f. } 1 .
$$

Pulcherrima hæc avis, cujus magnitudinem naturalem oftendit tabula, amat omnem Americam Auftralem, præcipue autem Brafiliam. 


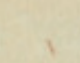





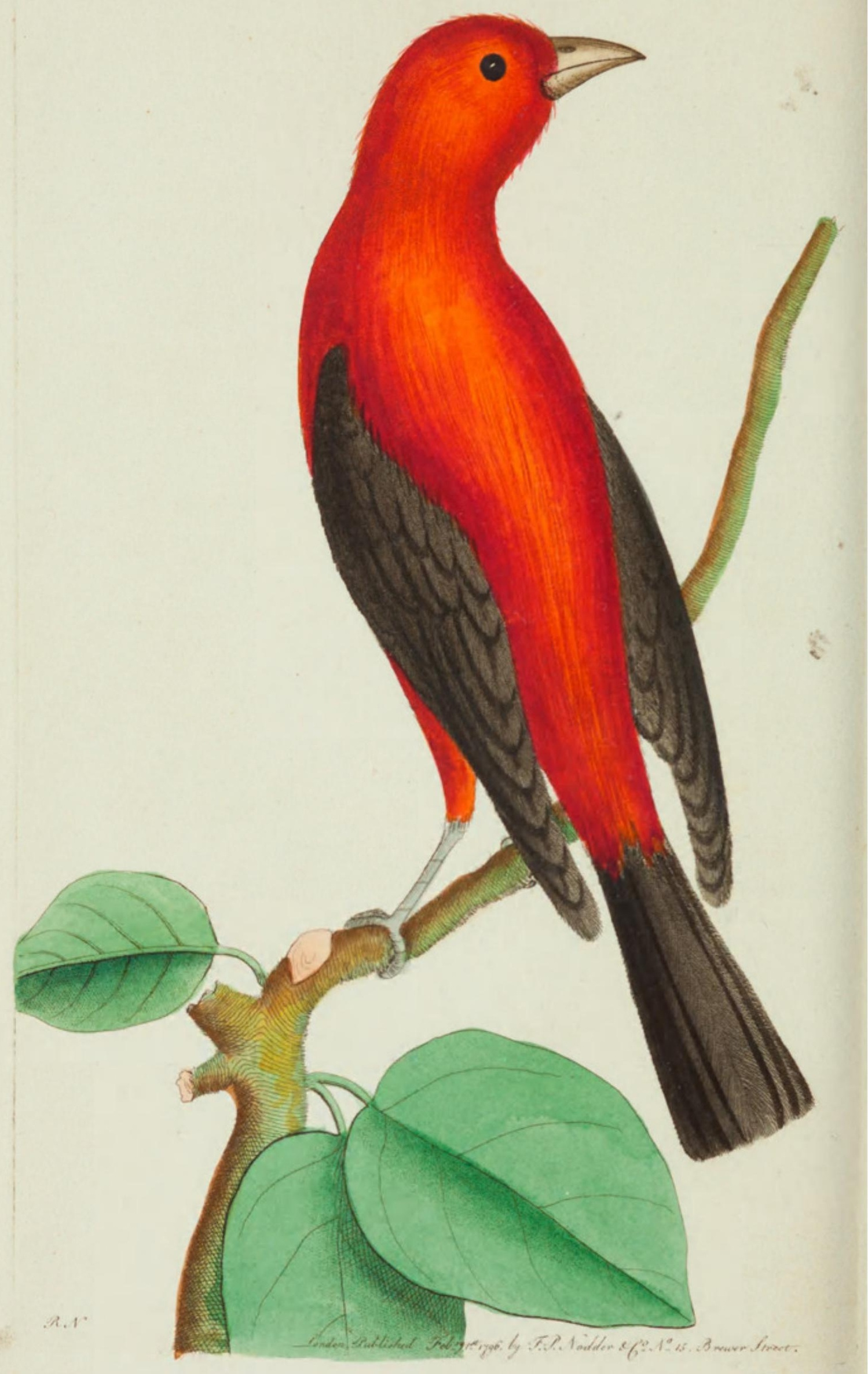


TH E

\section{BRASILIAN TANAGER.}

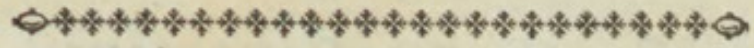

\section{GENERIC CHARACTER.}

Bill conic, fharp-pointed, floping at the tip and flightly emarginated; fomewhat trigonal towards the bafe.

$$
\text { SPECIFIC CHARACTER, EC. }
$$

SCARLET、 TANAGER with black wings and tail.

\section{Le CARDINAL.}

$$
\text { Brifl. orn. 3. p. } 42 \cdot 24 \text {. pl. 3. f. } 1 .
$$

BRASILIAN TANAGER.

$$
\text { Lath. Syn. 1. p. } 215 .
$$

This highly elegant fpecies is a native of South America, and is principally found in Brafil. The plate reprefents it in its natural fize. 


\section{$2 \mathrm{BHL}$ Biodiversity Heritage Library}

Shaw, George. 1796. "The Brasilian Tanager, Tanagra brasilia [PI. 234]." The Naturalist's Miscellany 7(LXXIX), https://doi.org/10.5962/p.310777.

View This Item Online: https://www.biodiversitylibrary.org/item/276356

DOI: https://doi.org/10.5962/p.310777

Permalink: https://www.biodiversitylibrary.org/partpdf/310777

\section{Holding Institution}

Museums Victoria

\section{Sponsored by}

Atlas of Living Australia

\section{Copyright \& Reuse}

Copyright Status: Public domain. The BHL considers that this work is no longer under copyright protection.

This document was created from content at the Biodiversity Heritage Library, the world's largest open access digital library for biodiversity literature and archives. Visit BHL at https://www.biodiversitylibrary.org. 